\title{
Aboveground biomass allometric equations and distribution of carbon stocks of the African oak (Afzelia africana Sm.) in Burkina Faso
}

\author{
Larba Hubert Balima ${ }^{1,2}$ - Blandine Marie Ivette Nacoulma ${ }^{2}$ Philippe Bayen ${ }^{2}$. \\ Kangbéni Dimobe $^{2,3} \cdot$ François N'Guessan Kouamé $^{1}$ - Adjima Thiombiano ${ }^{2}$
}

Received: 20 November 2018/ Accepted: 31 January 2019/Published online: 23 April 2019

(C) The Author(s) 2019

\begin{abstract}
The significant role of tropical forest ecosystems in the global carbon budget has increased the need for accurate estimates of tropical forest biomass. The lack of large-scale biomass allometric equations hampers the understanding of the spatial distribution of tree biomass and carbon stocks and their influencing factors in West Africa. This study aimed to develop allometric equations to estimate aboveground biomass of African oak (Afzelia africana Sm.) in Burkina Faso and to analyze factors affecting the variability of tree biomass and carbon storage. Sixty individual trees were destructively sampled in four protected areas along two climatic zones. In each climatic zone, log-log models were tested and fitted to each aboveground biomass component and to the total
\end{abstract}

Project funding: The project was fully funded by the German Federal Ministry of Education and Research (BMBF) through the West African Science Service Centre on Climate Change and Adapted Land Use (WASCAL) program.

The online version is available at http://www.springerlink.com

Corresponding editor: Zhu Hong.

Larba Hubert Balima

lhubertbalima@gmail.com

1 West African Science Service Centre on Climate Change and Adapted Land Use (WASCAL), Graduate Research Program on Climate Change and Biodiversity, UFR Biosciences, University Félix Houphoüet Boigny, B.P. 165, Abidjan 31, Côte d'Ivoire

2 Department of Plant Biology and Physiology, Laboratory of Plant Biology and Ecology, University Ouaga 1, Pr. Joseph Ki-Zerbo, 03 B.P. 7021, Ouagadougou 03, Burkina Faso

3 Laboratory of Botany and Plant Ecology, Department of Botany, University of Lomé, B.P. 1515, Lomé, Togo aboveground biomass. Carbon content in tree aboveground components was evaluated using the ash method. All validated equations showed good fit and performance with high explained variance. Allometric equations differed between the Sudano-sahelian zone and the Sudanian zone, except for leaf biomass equations. Both biomass allocation and carbon content varied significantly between tree components but not between climatic zones. Carbon content in tree components followed the patterns of biomass allocation with branches accounting for the highest proportion. In the two climatic zones, carbon contents were $50.18-52.62 \%$ for leaves, $54.78-54.94 \%$ for stems and $54.96-55.99 \%$ for branches. Dry biomass ranged from 509.05 to $765.56 \mathrm{~kg}^{-1} \mathrm{tree}^{-1}$ at site level and from 620.21 to $624.48 \mathrm{~kg} \mathrm{tree}^{-1}$ along climatic zones. Carbon content varied from $53.90 \%$ in the Sudano-sahelian zone to $54.39 \%$ in the Sudanian zone. This study indicated that climate does not influence aboveground biomass production and carbon sequestration of Afzelia africana along the Sudanosahelian and the Sudanian climatic zones of Burkina Faso. Future studies on climate-growth relationships should contribute to better understanding climate effects on biomass production and carbon storage.

Keywords African mahogany - Biomass allometry · Carbon storage $\cdot$ Climatic gradient $\cdot$ West Africa

\section{Introduction}

Global climate change has received growing attention with regard to the sustainable management of forest ecosystems. Indeed, forests sequester and store more carbon than any other terrestrial ecosystem (Gibbs et al. 2007). Thus, they represent the major terrestrial carbon sinks and pools 
(Gibbs et al. 2007; Pan et al. 2011), which play a significant role in the global carbon cycle (Fonseca et al. 2011; Vashum and Jayakumar 2012; Wani and Qaisar 2014). Because sustainably managed forests can greatly contribute to mitigating climate change (Wani and Qaisar 2014; Mensah et al. 2016a; Yang et al. 2017), economic incentives have been devised to offset carbon inputs by reducing emissions due to deforestation and forest degradation (REDD+). Nonetheless, the sustainability of REDD+ projects requires a clear understanding of the role of forests as both sinks and sources of carbon dioxide (Gibbs et al. 2007). Accounting for forestry-based projects in climate change mitigation policies thus requires accurate estimates of tropical carbon stocks.

Tropical forests are carbon-rich ecosystems accounting for 55\% of terrestrial carbon sinks (Pan et al. 2011) with aboveground biomass contributing the major carbon portion (Gibbs et al. 2007; Pan et al. 2011; Vashum and Jayakumar 2012). Hence, estimating aboveground biomass is critical for monitoring changes in carbon fluxes in tropical forests (Gibbs et al. 2007; Vashum and Jayakumar 2012) and assessing energy accumulation and the productivity and sustainability of forest ecosystems (Sawadogo et al. 2010; Vashum and Jayakumar 2012; Zeng et al. 2017). Biomass can be estimated by direct or indirect methods and remote sensing methods. The most accurate method to estimate tree biomass is destructive sampling (Gibbs et al. 2007; Basuki et al. 2009; Vashum and Jayakumar 2012; Mbow et al. 2013). This direct method allows the development of allometric equations, which can be used for converting ground-based measurements into biomass (Gibbs et al. 2007; Basuki et al. 2009).

In tropical African forests, biomass estimates are hampered by the lack of accurate allometric equations (Djomo et al. 2010, 2016; Henry et al. 2010). Therefore, many biomass estimates in Africa have relied on pantropical models (Chave et al. 2005, 2014). However, the applicability of such general equations in tropical African ecosystems is questionable (Basuki et al. 2009; Djomo et al. 2010; Henry et al. 2010). Accurate species- and ecosystem-specific allometric equations are therefore needed for reliable national ground-based monitoring, reporting, and verification of carbon stocks.

Over the last decade, much research effort in West Africa has gone into developing allometric equations for different forest types (Henry et al. 2010; Mbow et al. 2013), plantations (Bayen et al. 2015; Traoré et al. 2018) and tree species (Sawadogo et al. 2010; Dimobe et al. $2018 \mathrm{a}, \mathrm{b})$. Yet, how biomass and carbon stocks vary spatially and temporally at ecosystem and regional scales remains poorly understood. Numerous studies have suggested that biomass production and carbon storage are influenced by genetic variations, edaphic conditions (Henry et al. 2010; Sawadogo et al. 2010; Bayen et al. 2015) and land use and cover (Djomo et al. 2016; Qasim et al. 2016). Zhang et al. (2016) found that stand characteristics mostly explained variations in aboveground and belowground biomass. At the biome and global scale, climate is reported as the major factor influencing the distribution of terrestrial carbon pools (Pan et al. 2011). However, such controlling factors are rarely reflected in current biomass estimates of tropical African forests. So far, no published study in West Africa has attempted to assess the effects of climate variability on the patterns of biomass allocation and carbon contents in the various components of woody species. Accordingly, whether climate influences biomass production and carbon sequestration of woody species and whether biomass allometric equations are climate-specific remain unknown. Assessing the spatial distribution of tree biomass and carbon stocks is important to accurately report potential carbon sinks and sources through time and space. Such data are also essential for long-term monitoring of carbon stocks and sustainably managing tropical forests.

The present study addresses these issues through an endemic African timber species, the African oak (Afzelia africana Sm.; Fabaceae), well known for its wide distribution in Africa. This species is overexploited for its excellent quality timber, barks and foliage in Burkina Faso (Balima et al. 2018) and other African countries (Donkpegan et al. 2014). Despite the multipurpose uses and widespread distribution of A. africana, specific allometric equations for its biomass prediction are not available, limiting the assessment of its contribution to carbon mitigation. Hence, this study aimed to use destructive sampling to assess the variation patterns of biomass allocation and carbon content of $A$. africana, and their controlling factors. The specific objectives were to (1) establish, for each climatic zone, allometric equations to predict aboveground biomass of $A$. africana, (2) assess the patterns of biomass allocation and carbon content between tree components within sampled trees, and (3) to analyze the variations in biomass allometric equations, biomass allocation patterns and carbon content.

\section{Materials and methods}

\section{Study sites}

The study was conducted in four protected areas (PAs) of Burkina Faso: the W national park (WNP), the Nazinga game ranch (NGR), the wildlife reserve of Bontioli (WRB) and the classified forest of Comoé-Léraba (CFCL). The WNP $\left(11^{\circ} 54^{\prime}-12^{\circ} 35^{\prime} \mathrm{N}, 1^{\circ} 46^{\prime}-2^{\circ} 23^{\prime} \mathrm{E}\right)$ and the NGR $\left(11^{\circ} 01^{\prime}-11^{\circ} 18^{\prime} \mathrm{N}, 1^{\circ} 18^{\prime}-1^{\circ} 43^{\prime} \mathrm{W}\right)$ are located in the Sudano-sahelian climatic zone; the WRB $\left(10^{\circ} 70^{\prime}-10^{\circ} 95^{\prime} \mathrm{N}\right.$, 
$\left.3^{\circ} 02^{\prime}-3^{\circ} 20^{\prime} \mathrm{W}\right)$ and the CFCL $\left(9^{\circ} 25^{\prime}-11^{\circ} 5^{\prime} \mathrm{N}, 5^{\circ} 35^{\prime}-\right.$ $3^{\circ} 30^{\prime} \mathrm{W}$ ) are located in the Sudanian zone (Fig. 1). The choice of these PAs was based on the high abundance of $A$. africana populations. In the Sudano-sahelian zone, the main woody species encountered apart from Afzelia africana Sm. are Anogeissus leiocarpa (DC.) Guill. \& Perr., Combretum spp., Detarium microcarpum Guill. \& Perr., Isoberlinia doka Craib \& Stapf, Parkia biglobosa (Jacq.) R.Br. ex G.Don, Prosopis africana (Guill. \& Perr.) Taub., Terminalia spp. and Vitellaria paradoxa C.F.Gaertn. Burkea africana Hook., Daniellia oliveri (Rolfe) Hutch. \& Dalziel, Guibourtia copallifera Benn., Isoberlinia doka Craib \& Stapf, Isoberlina tomentosa Craib \& Stapf, Monotes kerstingii Gilg and Syzygium guineense (Willd.) DC represent the dominant species of the Sudanian zone. The main vegetation types in the four PAs are characterized by a mosaic of savannahs (shrub and tree savannas) and forests (woodland, dry forests and riparian forests). The climate is tropical with a unimodal rainfall regime of 4 to 6 months. The mean annual rainfall increases from the Sudano-sahelian zone to the Sudanian zone in contrast to the mean annual temperature which decreases (Table 1). As most protected areas in West Africa, the study sites greatly contribute to biodiversity conservation and the delivering of ecosystem services. Their conservation status and the soil types encountered in these sites are presented in Table 1 .

\section{Sampling design and data collection}

Forest inventories were carried out from April to June 2017. Overall, 144 plots were established in the PAs using an oriented stratified sampling. The plot sizes varied from $1000 \mathrm{~m}^{2}$ in savannas and dry forests to $500 \mathrm{~m}^{2}$ in riparian and dense forests (Thiombiano et al. 2016). Within each plot, tree height and stem diameter at breast height were measured for all individuals of $A$. africana with $\mathrm{dbh} \geq 5$ $\mathrm{cm}$. For biomass sampling, individuals of $A$. africana were grouped into different classes of $\mathrm{dbh}$. Individual trees from the most abundant classes were sampled (Mbow et al. 2013; Dimobe et al. 2018a). Then 60 individual trees (30 in

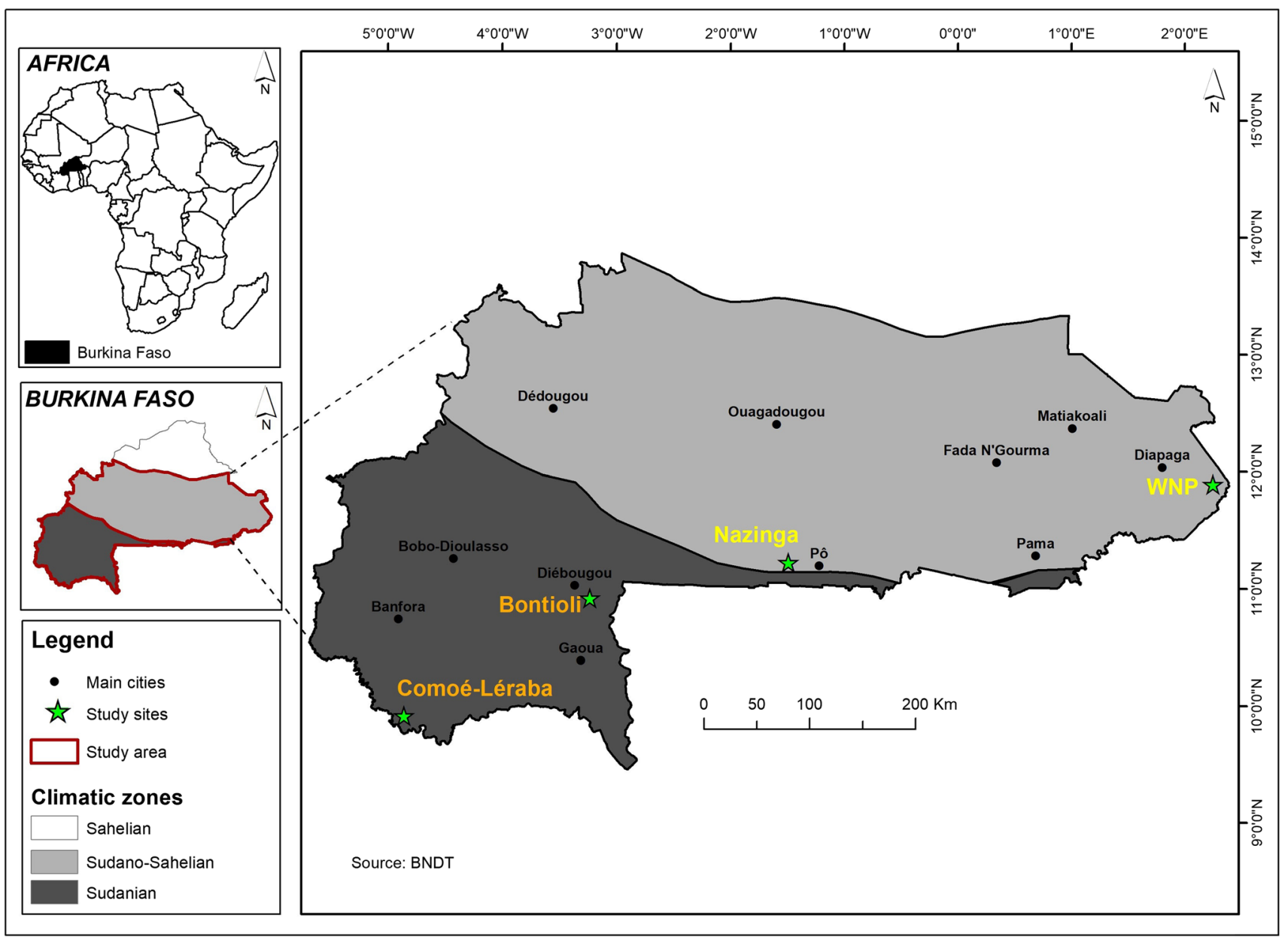

Fig. 1 Location of the study sites in Burkina Faso (West Africa). WNP, W national park 
Table 1 Characteristics of the four protected areas in Burkina Faso

\begin{tabular}{lrllll}
\hline Site & Area (ha) & IUCN category & MAR $(\mathrm{mm})$ & MAT $\left({ }^{\circ} \mathrm{C}\right)$ & Soil types \\
\hline WNP & 235,000 & II & $600-900$ & $30-25$ & luvisols, lixisols, leptosols \\
NGR & 91,000 & VI & $600-900$ & $30-25$ & ferruginous \\
WRB & 42,200 & I \& IV & $900-1000$ & $25-20$ & lixisols \\
CFCL & 125,000 & IV & $1000-1200$ & $25-20$ & ferric ferrasols \\
\hline
\end{tabular}

CFCL, classified forest of Comoé-Léraba; NGR, Nazinga game ranch; WNP, W national park; WRB, wildlife reserve of Bontioli; IUCN, International Union for Nature Conservation; MAR, mean annual rainfall; MAT, mean annual temperature each climatic zone) spanning different classes of diameters were harvested (Table 2).

Before tree harvesting, dbh, basal diameter $\left(d_{20}\right)$, crown diameter $(\mathrm{Cd})$ and tree height $(h)$ of all sampled trees were measured. Trees were cut at the base $(20 \mathrm{~cm}$ above the ground level) using a chain-saw. Felled trees were separated into leaves, branches and stem, and the fresh biomass of each component was weighed using a $100 \mathrm{~kg}$ scale balance. Thirty subsamples of leaves, branches and stem were collected at each site and weighed using an electronic balance (range $0-5 \mathrm{~kg}$, precision $1 \mathrm{~g}$ ). Theses subsamples were then transported to the laboratory and oven-dried at $105^{\circ} \mathrm{C}$ (branch and stem) and $75^{\circ} \mathrm{C}$ (leaves) until mass was constant. The ratio of dry mass to fresh mass for each tree component was determined, and the total dry aboveground biomass of each individual tree was computed by summing the dry biomasses of leaves, branches and stem.

\section{Development of allometric equations}

For each climatic zone, we developed allometric equations to predict each biomass component (leaves, branch and stem) and the total aboveground biomass (TAGB). The relationships between aboveground biomass and dendrometric variables (dbh, basal diameter, height, crown diameter) were graphically explored using several model types. The power function $y=\alpha x^{\beta} \varepsilon$ emerged as the best model that fit the observed data. This model was logarithmically transformed into its linear equivalent form defined as followed:

$\ln y=\ln \alpha+\beta \ln x+\varepsilon^{\prime}$,

where $y$ is the dependent variable (biomass), $x$ is the predictor, $\ln \alpha$ and $\beta$ are regression coefficients, and $\varepsilon^{\prime}$ the random error.

The best biomass equations were selected based on various goodness-of-fit statistics namely the adjusted $R$ square (Adj. $\mathrm{R}^{2}$ ), the Akaike information criterion (AIC), the residual standard error (RSE) and the root mean square error (RMSE). We also accounted for the global significance of the regression ( $p$ value) and the significance of the regression coefficients. Equations with higher $\mathrm{Adj} . \mathrm{R}^{2}$, smaller AIC, RSE and RMSE, and significant coefficients and $p$ value $(p<0.05)$ were selected as the best-fitted biomass allometric equations.

The systematic biases introduced by the logarithmic transformation were corrected using the correction factor defined below:

$\mathrm{CF}=\exp \left(\frac{\mathrm{RSE}^{2}}{2}\right)$

where $\mathrm{CF}$ is the correction factor and RSE is the residual standard error of the regression.
Table 2 Dendrometric variables of sampled trees across the study sites

\begin{tabular}{llllll}
\hline Study site & \multicolumn{1}{l}{ Range } & & & \\
\cline { 2 - 5 } & $\mathrm{dbh}(\mathrm{cm})$ & $d_{20}(\mathrm{~cm})$ & $h(\mathrm{~m})$ & $\mathrm{Cd}(\mathrm{m})$ & $N$ \\
\hline Sudano-sahelian zone & & & & & 30 \\
WNP & $18.46-49.02$ & $24.19-58.89$ & $7.2-12.90$ & $4.1-15.7$ & 15 \\
NGR & $20.37-49.33$ & $21.64-60.48$ & $5.8-13.2$ & $3.22-13.7$ & 15 \\
Sudanian zone & & & & & 30 \\
WRB & $22.28-54.11$ & $26.10-68.12$ & $7.4-14.9$ & $3.5-10.5$ & 13 \\
CFCL & $19.73-51.88$ & $22.6-57.29$ & $6.7-14.1$ & $4.7-16.3$ & 17 \\
\hline
\end{tabular}

CFCL, classified forest of Comoé-Léraba; NGR, Nazinga game ranch; WNP, W national park; WRB, wildlife reserve of Bontioli; $d_{20}$, basal diameter; $h$, tree height; $\mathrm{Cd}$, crown diameter; $N$, no. of sampled trees 


\section{Carbon content estimate}

The carbon content in tree components was estimated using the standard ash method (Allen et al. 1986). From the dry matters of subsamples collected for leaves, branch and stem, 60 composite samples (20 samples for each tree component) were collected. These composite samples were analyzed in the Laboratory of Plant Biology and Ecology (University Ouaga 1 Pr. Joseph Ki-Zerbo, Burkina Faso) using standard laboratory procedures for carbon content estimates (Bayen et al. 2015; Dimobe et al. 2018a). Carbon content was averaged for each biomass component based on the number of replicates and averaged for each individual tree. The carbon content of individual trees was then used to compute the mean carbon content for each site and each climatic zone.

\section{Statistical analyses}

The best fitted equations developed for biomass components were used to calculate leaf, branch and stem biomasses in each climatic zone. Biomass allocation to leaves, branches and stems was assessed by computing biomass fraction for each component. The TAGB allometric equations were used to compute tree dry aboveground biomass. The biomass of all trees was summed up to upscale to site and climatic zone levels based on the number of harvested trees. Carbon stocks were calculated by applying the mean carbon content. The paired $t$ test was used to seek for significant deviations between the observed and predicted values of biomass. The variations in biomass allocation and carbon content among tree components were analyzed using box plots and pairwise comparison of means (paired $t$ test). We also investigated the effects of climate on biomass and carbon content. We first applied a one-way analysis of variance (ANOVA) to determine whether tree size (dbh) and AGB differed between climatic zones. We further assessed whether and how carbon content varied with tree size (continuous variable) and climatic gradient (categorical variable) or the effects of their interactions. A generalized linear model (GLM) was performed using the formula:

$y=\alpha+\beta(\mathrm{dbh})+\gamma($ zone $)+\delta(\mathrm{dbh})($ zone $)$,

where $y$ equals mean carbon content (response variable); $\alpha$ is the intercept; $\beta, \gamma$ and $\delta$ are regression coefficients; zone is the categorical independent variable representing climatic zone, and dbh is the covariate. All statistical analyses were performed using $\mathrm{R}$ version 3.5.2 ( $\mathrm{R}$ Foundation for Statistical Computing, Vienna, Austria).

\section{Results}

\section{Aboveground biomass allometric equations}

Allometric equations fitted to biomass components showed AIC values between - 2.53 and 57.36, RSE between 0.217 and 0.589, and RMSE between 0.118 and 0.669 (Table 3). At both climatic zones, equations fitted to branch biomass showed high values of Adj. $\mathrm{R}^{2}$ (77.10-92.07\%), while leaf biomass equations had the lowest explained variance (48.52-73.12\%). Leaf biomass was better predicted for both climatic zones when basal diameter and crown diameter were used $\left(d_{20}^{2} \mathrm{Cd}\right)$ as compound variable (Eqs. 2 and 18). In the Sudanian zone, stem biomass was better estimated using basal diameter alone (Eq. 21), while in the Sudano-sahelian zone, tree height was added $\left(d_{20}^{2} h\right)$ as an additional predictor (Eq. 7). Using basal diameter and crown diameter $\left(d_{20}^{2} \mathrm{Cd}\right)$ as compound variable provided better estimation of branch biomass in the Sudanian zone (Eq. 26). However, in the Sudano-sahelian zone, branch biomass was predicted using basal diameter, crown diameter and tree height (Eq. 12).

Equations to predict the TAGB showed high adjusted $R^{2}$ with 91.13-96.81\% of explained variance. The AIC (- 24.38 to 9.88), RSE (0.150-0.267) and RMSE (0.1570.274 ) were also lower compared to those for equations fitted to biomass components. Equations using dbh as the lone predictor (Eqs. 13 and 29) showed RMSE values ranging from 0.157 to 0.189 , AIC from -24.38 to - 11.91, and the Adj. $\mathrm{R}^{2}$ between 95.71 and $96.81 \%$. Using tree $\mathrm{dbh}$ and height $\left(\mathrm{dbh}^{2} h\right)$ as a compound predictor for the TAGB (Eqs. 15 and 31) decreased the explained variance (91.13-94.40) and increased the AIC ( -6.43 to 9.88) and the RMSE $(0.252-0.274)$ in both climatic zones. However, adding crown diameter to $\mathrm{dbh}\left(\mathrm{dbh}^{2} \mathrm{Cd}\right)$ better estimated aboveground biomass in the Sudano-sahelian zone (Eq. 14). The use of $\mathrm{dbh}$, crown diameter and tree height as a compound predictor $\left(\mathrm{dbh}^{2} \mathrm{Cd}+h\right)$ did not significantly improve the model goodness of fit in the two climatic zones (Eqs. 16 and 32).

The best fitted biomass allometric equations are presented in Table 4. The relationships between tree biomass and structural variables varied according to the specificity of equations and climatic zones. Leaf biomass was better predicted at both zones using basal diameter and crown diameter $\left(d_{20}^{2} \mathrm{Cd}\right)$, while dbh alone was the best predictor for the TAGB in the Sudanian zone. Stem biomass was predicted using basal diameter alone in the Sudanian zone, while tree height was added $\left(d_{20}^{2} h\right)$ as an additional predictor in the Sudano-sahelian zone. The explained variance of fitted equations varied considerably among biomass components (68.13-92.07\%) in contrast to the TAGB 


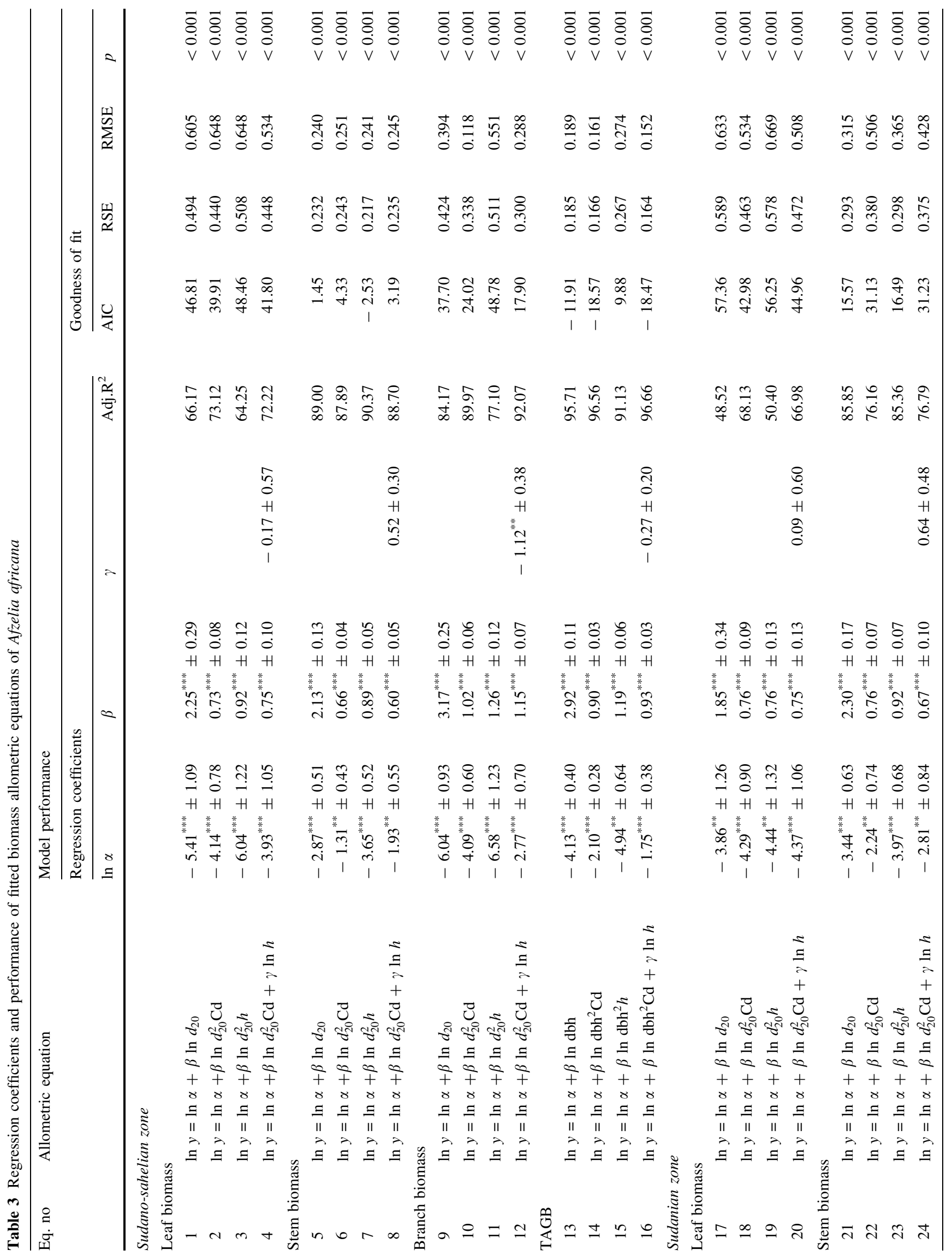




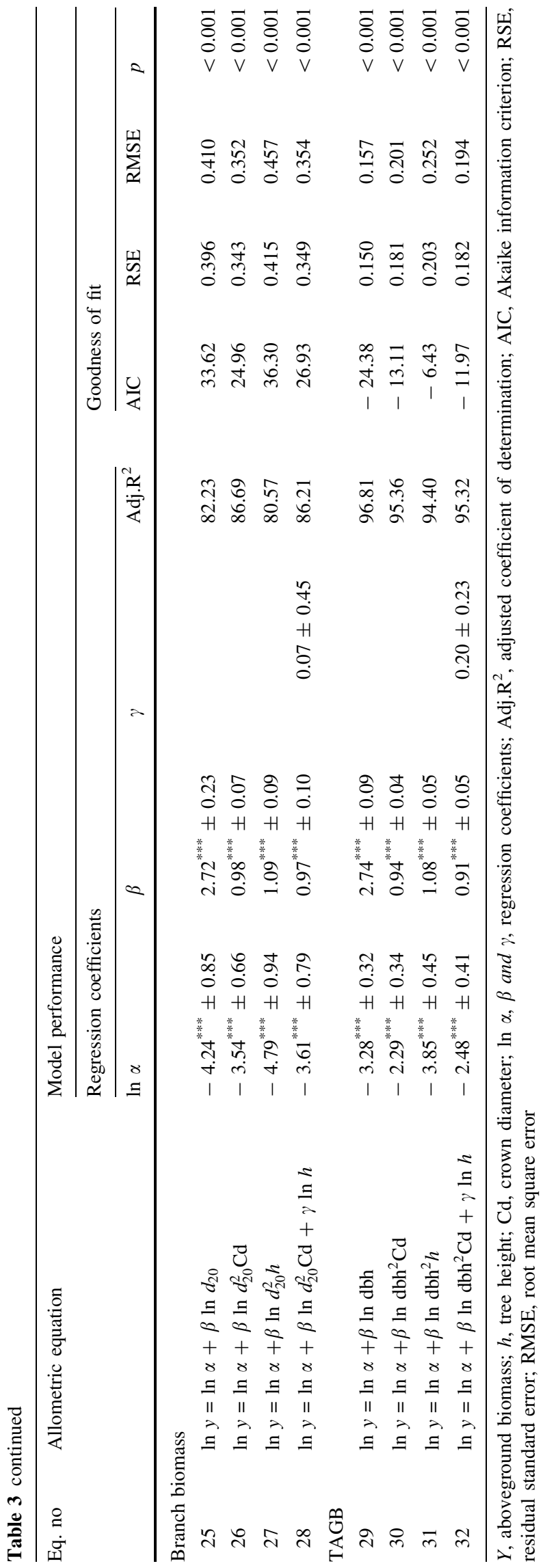

(96.56-96.81\%). The RSE and RMSE of fitted equations increased from the TAGB to biomass components (Table 4).

No significant deviation was observed between the observed and predicted values in the Sudano-sahelian zone for leaf biomass $(t=-0.431, d f=29, p=0.969)$, branch biomass $(t=0.320, d f=29, p=0.751)$ and stem biomass $(t=-0.739, d f=29, p=0.465)$. In the Sudanian zone, observed values and predicted values of biomass were also statistically similar for leaf ( $t=0.013, d f=29, p=0.989$ ), branch $(t=1.122, d f=29, p=0.270)$ and stem components $(t=0.194, d f=29, p=0.847)$. The observed and predicted values of TAGB did not significantly differ in the Sudano-sahelian zone $(t=0.035, d f=29, p=0.972)$ as well as the Sudanian zone $(t=0.381, d f=29$, $p=0.705)$. These results indicate good fit and performance of the selected allometric equations.

Scatter plots of observed versus predicted values of biomass showed a linear trend $(y=x)$, confirming the good performance of fitted log-log models (Fig. 2).

\section{Distribution of AGB and carbon content within tree components}

The box plots of biomass partitioning and carbon content of tree components (Fig. 3) showed that branches had the highest biomass fraction $(61.83 \% \pm 12.43$ and $63.43 \% \pm 11.90)$, followed by stems $(32.22 \% \pm 12.01$ and $33.95 \% \pm 11.89)$. Branches also had the highest carbon content in the Sudanian zone $(55.99 \% \pm 0.68)$. However, carbon content in branches $(54.96 \pm 0.61)$ was statistically similar to that in stems $(54.78 \pm 0.54)$ in the Sudano-sahelian zone $(p>0.05)$. In both climatic zones, leaves had the lowest biomass fraction (4.21-4.34\%) and the lowest carbon content (50.18-52.62\%). Both biomass allocation and carbon content varied significantly among leaves, branches and stems within each climatic zone $(p<0.001)$. Carbon content in leaves also varied significantly between the two climatic zones $(p<0.001)$. The same variations were observed for branch carbon content.

\section{Distribution of aboveground biomass and carbon across forests}

At the site level, the dry biomass production ranged between $509.05( \pm 476.52) \mathrm{kg}^{-1}$ tree $^{-1}$ at Comoé-Léraba to $765.56( \pm 541.95) \mathrm{kg}^{-1} \mathrm{tree}^{-1}$ at Bontioli (Table 5). However, the mean carbon contents varied from $53.76 \%$ $( \pm 1.38)$ at Bontioli to $55.02 \%( \pm 1.17)$ at Comoé-Léraba, with mean carbon stocks of $411.56 \mathrm{~kg} \mathrm{C}$ tree $^{-1}( \pm 291.35)$ and $280.07 \mathrm{~kg} \quad \mathrm{C}$ tree $^{-1}( \pm 262.18)$, respectively (Table 5). 
Table 4 Selected allometric equations for Afzelia africana biomass estimates in Burkina Faso

\begin{tabular}{|c|c|c|c|c|c|c|}
\hline Component & Allometric equation & Adj. $R^{2}$ & AIC & RSE & RMSE & $\mathrm{CF}$ \\
\hline \multicolumn{7}{|c|}{ Sudano-sahelian zone } \\
\hline Leaf & $\ln y=-4.14+0.73 \ln d_{20}^{2} \mathrm{Cd}$ & 73.12 & 39.91 & 0.440 & 0.648 & 1.137 \\
\hline Stem & $\ln y=-3.65+0.89 \ln d_{20}^{2} h$ & 90.37 & -2.53 & 0.217 & 0.241 & 1.029 \\
\hline Branch & $\ln y=-2.77+1.15 \ln d_{20}^{2} \mathrm{Cd}-1.12 \ln h$ & 92.07 & 17.90 & 0.300 & 0.288 & 1.046 \\
\hline TAGB & $\ln y=-2.10+0.90 \ln \mathrm{dbh}^{2} \mathrm{Cd}$ & 96.56 & -18.57 & 0.166 & 0.161 & 1.013 \\
\hline \multicolumn{7}{|c|}{ Sudanian zone } \\
\hline Leaf & $\ln y=-4.29+0.76 \ln d_{20}^{2} \mathrm{Cd}$ & 68.13 & 42.98 & 0.463 & 0.534 & 1.181 \\
\hline Stem & $\ln y=-3.44+2.30 \ln d_{20}$ & 85.85 & 15.57 & 0.293 & 0.315 & 1.043 \\
\hline Branch & $\ln y=-3.54+0.98 \ln d_{20}^{2} \mathrm{Cd}$ & 86.69 & 24.96 & 0.343 & 0.352 & 1.060 \\
\hline TAGB & $\ln y=-3.28+2.74 \ln \mathrm{dbh}$ & 96.81 & -24.38 & 0.150 & 0.157 & 1.011 \\
\hline
\end{tabular}

\section{Effects of climate on biomass production and carbon content}

The dry aboveground biomass varied from 18,606.19 tonnes in the Sudanian zone to $18,734.45$ tonnes in the Sudano-sahelian zone, with mean biomass production of $620.206 \quad( \pm 521.64) \mathrm{kg}$ tree $\mathrm{e}^{-1}$ to 624.48 $( \pm 429.45) \mathrm{kg}$ tree ${ }^{-1}$, respectively. The results of ANOVA (Table 6) showed no significant difference between the Sudano-sahelian zone and the Sudanian zone regarding dry biomass production. Similarly, no significant difference was observed between the two climatic zones regarding stem diameter of harvested trees.

Carbon content in aboveground components of $A$. africana ranged from $53.90 \% \pm 1.41$ (Sudano-sahelian zone) to $54.39 \% \pm 1.43$ (Sudanian zone). The mean carbon stocks were $336.59 \mathrm{~kg} \mathrm{C}$ tree $^{-1}( \pm 231.58)$ in the Sudanosahelian zone and $337.33 \mathrm{~kg} \mathrm{C}$ tree $^{-1}( \pm 282.81)$ in the Sudanian zone.

The results of GLM showed no significant effect of both tree size and climate on carbon content in tree components (Table 7). Similarly, the interactions between stem size and climate showed no significant effect on carbon content. The Sudanian zone was considered as a baseline in the model. It appears that trees of different size (dbh) have significantly similar carbon content within and across climatic zones.

\section{Discussion}

\section{Predictive power of allometric equations}

In this study, we developed allometric equations to estimate aboveground biomass of Afzelia africana across its distribution range in Burkina Faso. The fitted equations showed good performance with high explained variance. This confirms the accuracy of $\log -\log$ models, as widely reported in tropical African ecosystems (Fayolle et al. 2013; Djomo et al. 2016; Mensah et al. 2016a; Fonton et al. 2017) and elsewhere (Basuki et al. 2009; Xiang et al. 2016). The results revealed that the performance of allometric equations varied among tree biomass components within and between climatic zones. Among equations fitted to biomass components, branch equations explained the highest biomass variation while leaves displayed the lowest variation. The low variance observed for leaf equations could be explained by the fact that leaf biomass is less responsive to tree structural variables (Mensah et al. 2016b; Dimobe et al. 2018a). These results also confirm that biomass predictions are more accurate for large woody components than for smaller components (Sawadogo et al. 2010).

The high explained variance of the TAGB equations and the low values of AIC, RSE and RMSE highlight the accuracy and the suitability of allometric equations at site or ecosystem level (Paul et al. 2013; Djomo et al. 2016). This corroborates Paul et al. (2013) who reported that the precision and the accuracy of allometric equations increase with the level of specificity of equations. Allometric equations developed in this study can be used for biomass estimates of woody species throughout the respective climatic zones.

\section{Aboveground biomass and dendrometric relationships}

The relationships between aboveground biomass and tree dendrometric variables varied considerably between biomass components. Leaf biomass was better predicted using tree basal diameter and crown diameter $\left(d_{20}^{2} \mathrm{Cd}\right)$ as 
Fig. 2 Scatter plots of observed versus predicted values of total AGB in the Sudano-sahelian zone (a) and the Sudanian zone (b) of Burkina Faso. TAGB, total aboveground biomass

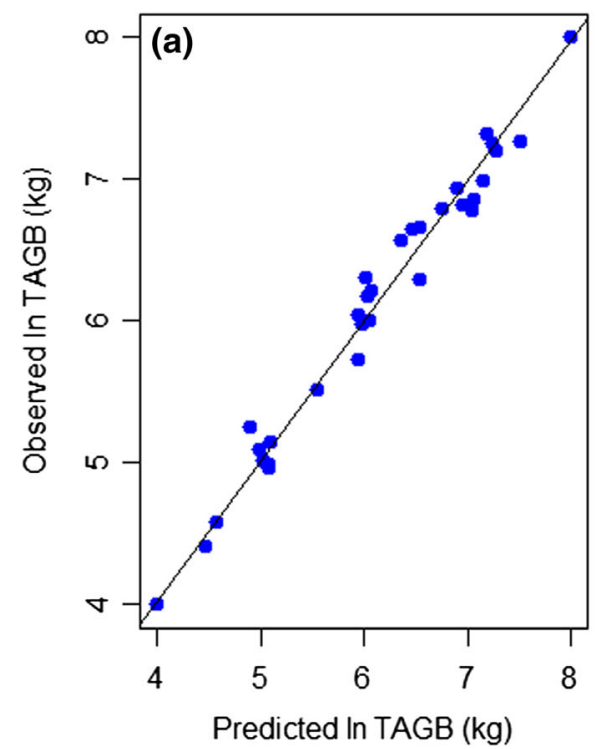

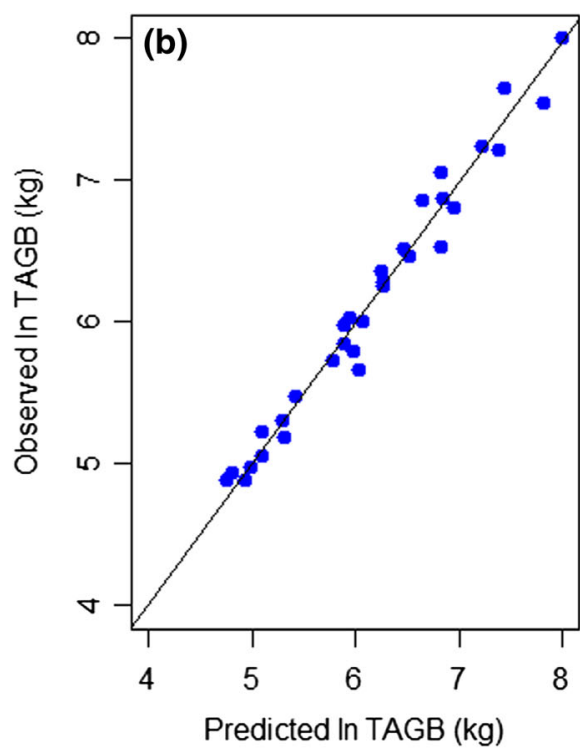

Sudano-sahelian zone
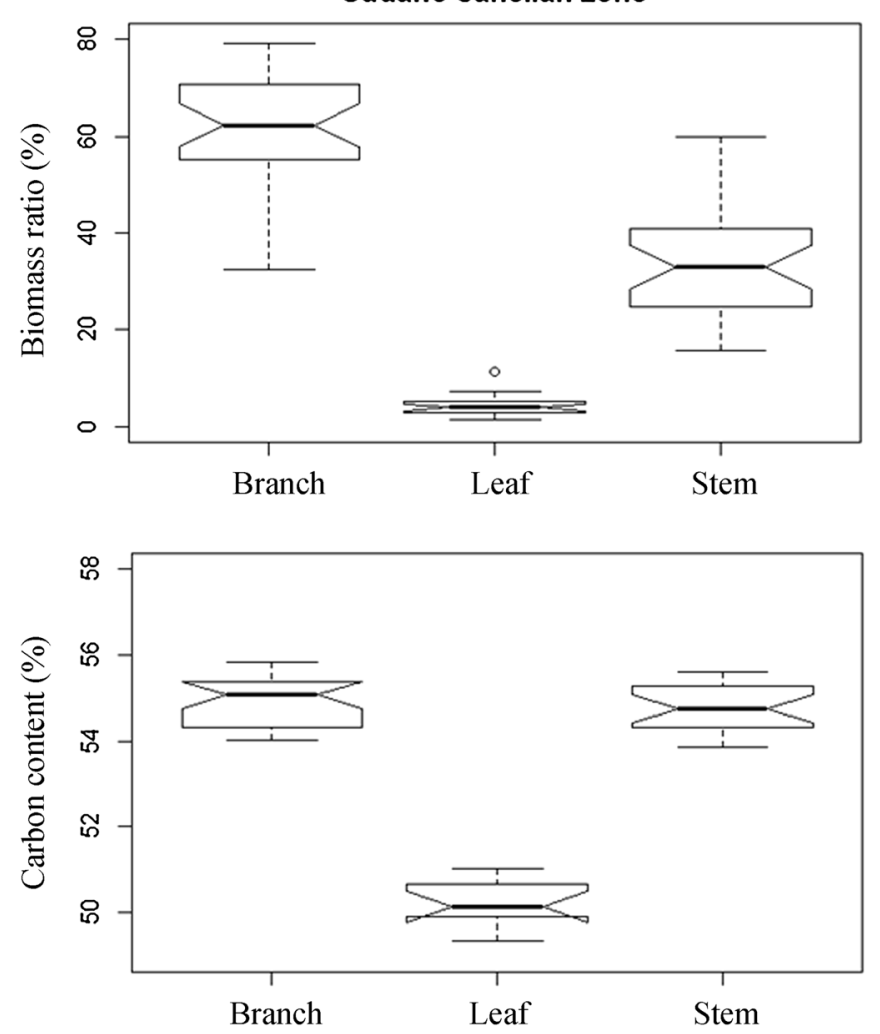

Sudanian zone
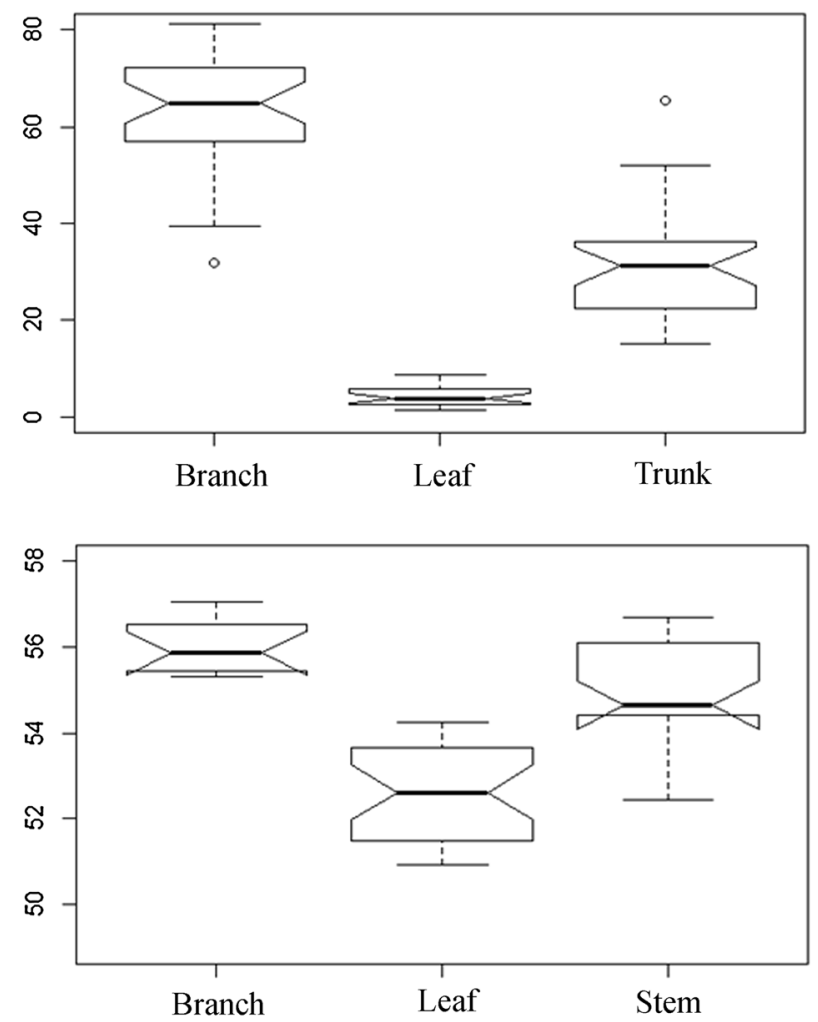

Fig. 3 Biomass partitioning and carbon content in tree components of Afzelia africana in Burkina Faso. Biomass ratio (\%), biomass fraction for each tree component

compound predictor. Tree basal diameter and crown diameter were also the best predictors for branch biomass. Equations to predict the TAGB were based on tree dbh and crown diameter. Such variations of allometric equations are in line with previous findings in Burkina Faso (Sawadogo et al. 2010; Bayen et al. 2015; Dimobe et al. 2018a), Ghana
(Henry et al. 2010) and Côte d'Ivoire (Traoré et al. 2018). The use of different sets of predictors also corroborates previous published equations where stem dbh was used as the lone predictor of woody species aboveground biomass or in combination with tree height and/or crown diameter (Kuyah et al. 2012; Mbow et al. 2013; Mensah et al. 
Table 5 Dry biomass production, carbon content and carbon stocks of Afzelia africana across protected areas in Burkina Faso

\begin{tabular}{llll}
\hline Sites & Dry AGB $\left(\mathrm{kg} \mathrm{tree}^{-1}\right)$ & C content $(\%)$ & C stock $\left(\mathrm{kg} \mathrm{C} \mathrm{tree}^{-1}\right)$ \\
\hline PNW & $545.18 \pm 415.73$ & $53.77 \pm 1.58$ & $293.14 \pm 223.54$ \\
NGR & $704.91 \pm 428.10$ & $54.01 \pm 1.22$ & $380.72 \pm 223.21$ \\
WRB & $765.56 \pm 541.95$ & $53.76 \pm 1.38$ & $411.56 \pm 291.35$ \\
CFCL & $509.05 \pm 476.52$ & $55.02 \pm 1.17$ & $280.07 \pm 262.18$ \\
\hline
\end{tabular}

CFCL, classified forest of Comoé-Léraba; NGR, Nazinga game ranch; WNP, W national park; WRB, wildlife reserve of Bontioli
Table 6 Results of the ANOVA showing the effects of climate on biomass production and tree size of Afzelia africana in Burkina Faso

\begin{tabular}{lrllll}
\hline Variable & $d f$ & SS & MS & $F$ & $\operatorname{Pr}(>F)$ \\
\hline $\begin{array}{l}\text { Dry AGB } \\
\text { Climate }\end{array}$ & 1 & 0.002 & 0.0018 & 1.014 & 0.973 \\
Residuals & 58 & 7.976 & 0.137 & & \\
Stem dbh & & & & & \\
Climate & 1 & 0.002 & 0.0018 & 0.013 & 0.909 \\
Residuals & 58 & 8.310 & 0.1432 & & \\
\hline
\end{tabular}

SS, sum of squares; MS, mean square; AGB, aboveground biomass

2016a, b; Xiang et al. 2016; Dimobe et al. 2018b). The observed variations confirm the assumption that biomass predictors are specific to tree components (Dimobe et al. 2018a).

Our findings further showed that biomass allometric equations are specific to climatic zones. Indeed, different sets of predictors were used in the Sudano-sahelian zone and the Sudanian zone to predict stem biomass, branch biomass and the total AGB. These findings indicate that climate influences the relationships between tree biomass and its structural variables. The observed variations highlight the within-species variations of biomass allometric equations and could be explained by differences in tree growth patterns along the Sudano-sahelian and the Sudanian zones. Such differences in tree growth patterns (radial and height) due to climate variability could influence allometric equations through variations in biomass allocation patterns. The variations in biomass allometric equations could be also attributed to differences in tree canopy architecture and branching patterns, competition, soil conditions (Chave et al. 2005; Djomo et al. 2010; Sawadogo et al. 2010; Xiang et al. 2016) and anthropogenic disturbances such as pruning. Future studies on the influence of climate on tree growth are needed to better understand climate effects on biomass allometric equations.

The use of stem dbh as the best predictor for the total aboveground biomass corroborates several studies from tropical savannas and forests (Basuki et al. 2009; Sawadogo et al. 2010; Kuyah et al. 2012; Mbow et al. 2013) to subtropical ecosystems (Paul et al. 2013; Xiang et al. 2016; Zeng et al. 2017). However, adding tree height as an additional biomass predictor $\left(\mathrm{dbh}^{2} h\right)$ did not improve the TAGB equations, as reported in earlier studies (Henry et al. 2010; Picard et al. 2015; Djomo et al. 2016; Mensah et al. 2016a, b). Stem dbh has been advocated as the most accurate biomass predictor for species-level regression models (Mbow et al. 2013; Xiang et al. 2016) to reduce errors inherent to the measurements of the other biomass predictors.

\section{Distribution of aboveground biomass and carbon}

The study showed that biomass partitioning varied between tree components with branch accounting for two-thirds of the total dry AGB. This result is consistent with findings on $V$. paradoxa C.F.Gaertn. in Burkina Faso where branch exhibited the highest biomass fraction (Dimobe et al. 2018a). The pattern in biomass allocation of A. africana also follows that of $C$. glutinosum Perr. ex DC. and $T$. laxiflora Engl. \& Diels (Dimobe et al. 2018b). However, tree stem was reported elsewhere as the greatest biomass fraction (Henry et al. 2010; Sawadogo et al. 2010; Fonseca et al. 2011; Traoré et al. 2018). The variations in biomass
Table 7 Results of the GLM showing the effects of tree size and climate on carbon content of Afzelia africana in Burkina Faso

\begin{tabular}{llclll}
\hline Independent variable & Model parameters & & & \\
\cline { 2 - 6 } & Covariate levels & Estimate & SE & \multicolumn{1}{l}{$z$} & $\operatorname{Pr}(>|z|)$ \\
\hline \multirow{2}{*}{ Tree dbh } & Intercept & 0.564 & 0.596 & 0.947 & 0.344 \\
Climate & ln dbh & -0.0004 & 0.017 & -0.024 & 0.981 \\
Tree dbh: Climate & Sudano-sahelian & -0.009 & 0.939 & -0.010 & 0.992 \\
\hline
\end{tabular}


allocation patterns within and between species could be explained by the specific eco-physiological responses of woody plants to environmental factors. The findings also showed an increasing trend in carbon content from leaves to branches with significant variations between tree components. This corroborates several studies conducted in tropical ecosystems (Negi et al. 2003; Fonseca et al. 2011; Wani and Qaisar 2014; Bayen et al. 2015; Dimobe et al. 2018a). Our results suggest that the more biomass allocated to a given tree component, the higher the carbon will be stored in that part (Negi et al. 2003). These findings also confirm that lower biomass and lower carbon are allocated to tree functional organs (leaves and roots), while more biomass and carbon are allocated to woody organs (Negi et al. 2003; Fonseca et al. 2011; Bayen et al. 2015; Dimobe et al. 2018a).

At the ecosystem level and compared to other local species, the mean dry AGB of A. africana was greater than values predicted for $V$. paradoxa C.F.Gaertn. (153.86 kg ind ${ }^{-1}$ ) in Burkina Faso (Dimobe et al. 2018a). The value was also higher than biomass predicted for $A$. leiocarpus (DC.) Guill. \& Perr., C. febrifuga (Afzel. ex G.Don) Benth. and A. dudgeoni Craib ex Holland in the Sudanian zone (Sawadogo et al. 2010). The mean carbon content of A. africana varied from $53.90 \%$ to $54.39 \%$. Similar values were reported on J. curcas L. (Bayen et al. 2015) and V. paradoxa C.F.Gaertn. (Dimobe et al. 2018a) for which mean carbon contents of $51 \%$ and $55.49 \%$, respectively, were reported. However, the mean values of carbon content in A. africana are above the default value suggested by IPCC (50\%). Therefore, applying such a standard conversion factor might underestimate carbon stocks of the species, as also pointed out in previous studies (Fonseca et al. 2011; Bayen et al. 2015; Dimobe et al. 2018a).

\section{Factors influencing biomass production and carbon storage}

The study revealed that biomass fractions for each tree component were statistically similar between the two climatic zones. However, leaf carbon content and branch carbon content varied between the Sudano-sahelian and the Sudanian zones. Such variations imply that climate influences carbon allocation to leaf and branch. The mean dry AGB did not differ between the two climatic zones. This similarity in dry AGB was consistent with tree diameters (dbh), which were also similar across climatic zones. These results corroborate the fact that biomass production is tree size dependent (Basuki et al. 2009; Sawadogo et al. 2010; Kuyah et al. 2012; Mbow et al. 2013; Mensah et al. 2016a). Such a relationship between biomass and tree size was also consistent with the high dry AGB value predicted at
Bontioli (though not significant), where big trees were harvested due to the lower abundance of smaller individuals.

Carbon content of A. africana was neither tree size (dbh) dependent nor climate dependent. The similarities observed in dry AGB and carbon content across the two climatic zones could be attributed to low climatic variation between the Sudanian and the Sudano-sahelian zones of Burkina Faso. Similar results were reported by Qasim et al. (2016) who attributed the similarity in dry AGB stocks between Nazinga and Bontioli to similar environmental conditions. Yet, although no significant variations were found between climatic zones regarding dry biomass and carbon content, an increasing trend in carbon content was found from the driest site $(53.77 \%$ at WNP) to the most humid forest (55.02\% at CFCL). The mean carbon content also slightly increased from the Sudano-sahelian zone $(53.90 \%)$ to the Sudanian zone $(54.39 \%)$. Such increasing trend in carbon content followed a North-South climatic gradient characterized by an increase in the mean annual rainfall (600-900 $\mathrm{mm} \mathrm{year}^{-1}$ to $1000-1200 \mathrm{~mm} \mathrm{year}^{-1}$ ) and a decrease in the mean annual temperature $\left(30-25{ }^{\circ} \mathrm{C}\right.$ to $\left.25-20{ }^{\circ} \mathrm{C}\right)$. These variations with climatic gradient, although not statistically significant, could imply that climate influences carbon storage. Similar findings were reported previously (Schippers et al. 2015; Zhao et al. 2017) and demonstrated that carbon storage was strongly correlated with mean annual temperature and mean annual precipitation. In fact, high temperatures in tropical forests induce higher evapotranspiration and water stress, reducing therefore photosynthesis, tree growth, biomass production (Schippers et al. 2015) and carbon sequestration. The observed low variation in carbon content also corroborates the results of Zhang et al. (2016) that $2-4 \%$ of carbon variation is due to climate. Our results highlight that the magnitude to which climate can influence biomass production and carbon storage depends on the amplitude of the climate variability. The findings call for extensive research to investigate the influence of rainfall and temperature variability on tree growth patterns and biomass accumulation for a better understanding of the spatial distribution of forest carbon stocks. Similar studies on other woody species and ecosystems are also needed in other environmental conditions for thorough insights into the coupling between climate and carbon storage.

\section{Conclusions}

This study analyzed the spatial variability in biomass allometric equations and carbon stocks of the African oak tree. The findings revealed that climate influences biomass allometric equations. The established equations can be used 
for accurate biomass estimates of woody species throughout the Sudano-sahelian and the Sudanian climatic zones. The results also showed that carbon content of $A$. africana was not tree-size dependent as biomass production. Biomass production, carbon contents and carbon stocks did not vary between the Sudanian and the Sudano-sahelian zones. However, climate influences carbon allocation to leaf and branch components. The findings highlighted that climate might influence biomass production and carbon storage of woody species at a wider geographical scale. Testing specific and mixed allometric models in different climatic zones could improve our understanding on the factors driving the spatial distribution of carbon stocks. Assessing climate-growth relationships along the two climatic zones is also essential for understanding the coupling between climate and biomass accumulation. Such data is of great relevance for making accurate inferences about the longterm dynamics of tropical forests and their potential carbon stocks.

Acknowledgements The authors are grateful to the German Federal Ministry of Education and Research (BMBF), for providing financial and excellent academic support through the Graduate Research Program (GRP) Climate Change and Biodiversity of the WASCAL program. The authors are also grateful to the Ministry of Environment, Green Economy and Climate Change of Burkina Faso, which facilitated access to the protected areas.

Open Access This article is distributed under the terms of the Creative Commons Attribution 4.0 International License (http://crea tivecommons.org/licenses/by/4.0/), which permits unrestricted use, distribution, and reproduction in any medium, provided you give appropriate credit to the original author(s) and the source, provide a link to the Creative Commons license, and indicate if changes were made.

\section{References}

Allen SE, Grimshaw HM, Rowland AP (1986) Chemical analysis. In: Moore PD, Chapman SB (eds) Methods of plant ecology. Blackwell, Oxford, pp 285-344

Balima LH, Nacoulma BMI, Ekué MRM, Kouamé NF, Thiombiano A (2018) Use patterns, use values and management of Afzelia africana Sm. in Burkina Faso: implication for domestication and sustainable conservation. J Ethnobiol Ethnomed 14(23):1-14. https://doi.org/10.1186/s13002-018-0221-z

Basuki TM, van Laake PE, Skidmore AK, Hussin YA (2009) Allometric equations for estimating the above-ground biomass in tropical lowland Dipterocarp forests. For Ecol Manag 257:1684-1694. https://doi.org/10.1016/j.foreco.2009.01.027

Bayen P, Bognounou F, Lykke AM, Ouédraogo M, Thiombiano A (2015) The use of biomass production and allometric models to estimate carbon sequestration of Jatropha curcas L. plantations in western Burkina Faso. Environ Dev Sustain 17(1):1-16. https://doi.org/10.1007/s10668-015-9631-4

Chave J, Andalo C, Brown S, Cairns MA, Chambers JQ, Eamus D, Fölster H, Fromard F, Higuchi N, Kira T, Lescure J-P, Nelson BW, Ogawa H, Puig H, Riéra B, Yamakura T (2005) Tree allometry and improved estimation of carbon stocks and balance in tropical forests. Ecosyst Ecol 145:78-99. https://doi.org/10. 1007/s00442-005-0100-x

Chave J, Rejou Mechain M, Burquez A, Chidumayo E, Colgan MS, Delitti WBC, Duque A, Eid T, Fearnside PM, Goodman RC, Henry M, Martinez-Yrizar A, Mugasha WA, Muller-Landau HC, Mencuccini M, Nelson BW, Ngomanda A, Nogueira EM, OrtizMalavassi E, Pélissier R, Ploton P, Ryan CM, Saldarriaga JG, Vieilledent $G$ (2014) Improved allometric models to estimate the above ground biomass of tropical trees. Glob Change Biol 20:3177-3190. https://doi.org/10.1111/gcb.12629

Dimobe K, Goetze D, Ouédraogo A, Mensah S, Akpagana K, Porembski S, Thiombiano A (2018a) Aboveground biomass allometric equations and carbon content of the shea butter tree (Vitellaria paradoxa CF Gaertn., Sapotaceae) components in Sudanian savannas (West Africa). Agrofor Syst 71(3):1-14. https://doi.org/10.1007/s10457-018-0213-y

Dimobe K, Mensah S, Goetze D, Ouédraogo A, Kuyah S, Porembski S, Thiombiano A (2018b) Aboveground biomass partitioning and additive models for Combretum glutinosum and Terminalia laxiflora in West Africa. Biomass Bioenergy 115:151-159. https://doi.org/10.1016/j.biombioe.2018.04.022

Djomo AN, Ibrahima A, Saborowski J, Gravenhorst G (2010) Allometric equations for biomass estimations in Cameroon and pan moist tropical equations including biomass data from Africa. For Ecol Manag 260:1873-1885. https://doi.org/10.1016/j. foreco.2010.08.034

Djomo AN, Picard N, Fayolle A, Henry M, Ngomanda A, Ploton P, McLellan J, Saborowski J, Adamou I, Lejeune P (2016) Tree allometry for estimation of carbon stocks in African tropical forests. Forestry 89:446-455. https://doi.org/10.1093/forestry/ cpw025

Donkpegan ASL, Hardy OJ, Lejeune P, Oumorou M, Daïnou K, Doucet J-L (2014) Un complexe d'espèces d'Afzelia des forêts africaines d'intérêt économique et écologique (synthèse bibliographique). Biotechnol Agron Soc Environ 18(2):233-246

Fayolle A, Doucet JL, Gillet JF, Bourland N, Lejeune P (2013) Tree allometry in Central Africa: testing the validity of pantropical multi-species allometric equations for estimating biomass and carbon stocks. For Ecol Manag 305:29-37. https://doi.org/10. 1016/j.foreco.2013.05.036

Fonseca W, Alice FE, Rey-Benayas JM (2011) Carbon accumulation in aboveground and belowground biomass and soil of different age native forest plantations in the humid tropical lowlands of Costa Rica. New For 43(2):197-211. https://doi.org/10.1007/ s11056-011-9273-9

Fonton NH, Medjibé V, Djomo A, Kondaoulé J, Rossi V, Ngomanda A, Maïdou H (2017) Analyzing accuracy of the power functions for modeling aboveground biomass prediction in Congo basin tropical forests. Open J For 7:388-402. https://doi.org/10.4236/ ojf.2017.74023

Gibbs HK, Brown S, Niles JO, Jonathan A, Foley JA (2007) Monitoring and estimating tropical forest carbon stocks: making REDD a reality. Environ Res Lett 2:1-13. https://doi.org/10. 1088/1748-9326/2/4/045023

Henry M, Besnard A, Asante WA, Eshun J, Adu-Bredu SA, Valentini R, Bernoux M, Saint-André L (2010) Wood density, phytomass variations within and among trees, and allometric equations in a tropical rainforest of Africa. For Ecol Manag 260:1375-1388. https://doi.org/10.1016/j.foreco.2010.07.040

Kuyah S, Dietz J, Muthuri C, Jamnadass R, Mwangi P, Coe R, Neufeldt H (2012) Allometric equations for estimating biomass in agricultural landscapes: I. Aboveground biomass. Agr Ecosyst Environ 158:216-224. https://doi.org/10.1016/j.agee.2012.05. 011

Mbow C, Verstraete MM, Sambou B, Diaw AT, Neufeldt H (2013) Allometric models for aboveground biomass in dry savanna trees 
of the Sudan and Sudan Guinean ecosystems of Southern Senegal. J For Res 19:340-347. https://doi.org/10.1007/s10310013-0414-1

Mensah S, Veldtman R, du Toit B, Glèlè Kakaï R, Seifert T (2016a) Aboveground biomass and carbon in a South African mistbelt forest and the relationships with tree species diversity and forest structures. Forests 79:1-17. https://doi.org/10.3390/f7040079

Mensah S, Veldtman R, Seifert T (2016b) Allometric models for height and aboveground biomass of dominant tree species in South African Mistbelt forests. South For J For Sci 79:19-30. https://doi.org/10.2989/20702620.2016.1225187

Negi JDS, Manhas RK, Chauhan PS (2003) Carbon allocation in different components of some tree species of India: a new approach for carbon estimation. Curr Sci 85(11):1528-1531

Pan Y, Birdsey RA, Fang J, Houghton R, Kauppi PE, Kurz WA, Philips OL, Shvidenko A, Lewis SL, Canadell JG, Ciais P, Jackson RB, Pacala SW, McGuire AD, Piao S, Rautiainen A, Sitch S, Hayes D (2011) A large and persistent carbon sink in the world's forests. Science 333(80):988-993. https://doi.org/10. 1126/science. 1201609

Paul KI, Roxburgh SH, Ritson P, Brooksbank K, England JR, Larmour JS, Raison RJ, Peck A, Wildy DT, Sudmeyer RA, Giles R, Carter J, Bennett R, Mendham DS, Huxtable D, Bartle JR (2013) Testing allometric equations for prediction of aboveground biomass of mallee eucalypts in southern Australia. For Ecol Manag 310:1005-1015. https://doi.org/10.1016/j.foreco. 2013.09.040

Picard N, Rutishauser E, Ploton P, Ngomanda A, Henry M (2015) Should tree biomass allometry be restricted to power models? For Ecol Manag 353:156-163. https://doi.org/10.1016/j.foreco. 2015.05.035

Qasim M, Porembski S, Sattler D, Stein K, Thiombiano A, Lindner A (2016) Vegetation structure and carbon stocks of two protected areas within the South-Sudanian Savannas of Burkina Faso. Environments 3(25):1-16. https://doi.org/10.3390/ environments3040025

Sawadogo L, Savadogo P, Tiveau D, Dayamba SD, Zida D, Nouvellet Y, Oden PC, Guinko S (2010) Allometric prediction of aboveground biomass of eleven woody tree species in the Sudanian savanna-woodland of West Africa. J For Res 21(4):475-481. https://doi.org/10.1007/s11676-010-0101-4

Schippers P, Sterck F, Vlam M, Zuidema PA (2015) Tree growth variation in the tropical forest: understanding effects of temperature, rainfall and $\mathrm{CO}_{2}$. Glob Change Biol 21:2749-2761. https://doi.org/10.1111/gcb.12877
Thiombiano A, Glèlè Kakaï R, Bayen P, Boussim IJ, Mahamane A (2016) Méthodes et dispositifs d'inventaires forestiers en Afrique de l'Ouest: état des lieux et propositions pour une harmonisation. Methodes de collecte et d'analyse des données de terrain pour l'évaluation et le suivi de la végétation en Afrique, Annales des Sciences Agronomiques 20:15-31

Traoré S, Djomo AN, N'guessan AK, Coulibaly B, Ahoba A, Gnahoua GM, N'guessan EK, Adou Yao CY, N'Dja JK, Guede NZ (2018) Stand structure, allometric equations, biomass and carbon sequestration capacity of Acacia mangium Wild. (Mimosaceae) in Cote d'Ivoire. Open J For 8:42-60. https://doi.org/ 10.4236/ojf.2018.81004

Vashum KT, Jayakumar S (2012) Methods to estimate above-ground biomass and carbon stock in natural forests-a review. Ecosyst Ecogr 2(116):1-7. https://doi.org/10.4172/2157-7625.1000116

Wani NR, Qaisar KN (2014) Carbon percent in different components of tree species and soil organic carbon pool under these tree species in Kashmir Valley. Curr World Environ 9(1):174-181. https://doi.org/10.12944/CWE.9.1.24

Xiang W, Zhou J, Ouyang S, Zhang S, Lei P, Li J, Deng X, Fang X, Forrester DI (2016) Species-specific and general allometric equations for estimating tree biomass components of subtropical forests in southern China. Eur J For Res 135:963-979. https:// doi.org/10.1007/s10342-016-0987-2

Yang J, Ji X, Deane DC, Wu L, Chen S (2017) Spatiotemporal distribution and driving factors of forest biomass carbon storage in China: 1977-2013. Forests 8(263):1-14. https://doi.org/10. 3390/f8070263

Zeng WS, Duo HR, Lei XD, Chen XY, Wang XJ, Pu Y, Zou WT (2017) Individual tree biomass equations and growth models sensitive to climate variables for Larix spp. in China. Eur J For Res 136:233-249. https://doi.org/10.1007/s10342-017-1024-9

Zhang H, Song T, Wang K, Yang H, Yue Y, Zeng Z, Peng W, Zeng F (2016) Influences of stand characteristics and environmental factors on forest biomass and root-shoot allocation in southwest China. Ecol Eng 91:7-15. https://doi.org/10.1016/j.ecoleng. 2016.01.040

Zhao Y, Ding Y, Hou X, Li FY, Han W, Yun X (2017) Effects of temperature and grazing on soil organic carbon storage in grasslands along the Eurasian steppe eastern transect. PLoS ONE 12(10):1-16. https://doi.org/10.1371/journal.pone.0186980

Publisher's Note Springer Nature remains neutral with regard to jurisdictional claims in published maps and institutional affiliations. 